\title{
Change and Continuity in Newspaper Coverage of Popular Music since 1955: Evidence from the United States, France, Germany, and the Netherlands
}

\author{
Vaughn Schmutz, Alex van Venrooij, Susanne Janssen, Marc Verboord
}

In this article, we describe general features of popular music coverage in elite newspapers in the United States, France, Germany, and the Netherlands from 1955 to 2005. Drawing on data from content analysis of over 4,000 newspaper articles sampled in four reference years $(1955,1975,1995$, and 2005), we document broad changes and continuities in the extent, focus, and form of popular music coverage in mainstream media outlets of each country.

In any art world, media discourse plays an important institutional role in distributing recognition and prestige to certain types of people and productions (Becker). Through such discourse, music critics act as "gatekeepers of taste" (Shuker 92), operating as cultural intermediaries who shape opinions and perceptions about different types of music and musicians through the evaluations and interpretations they offer. As such, media discourse represents a valuable resource for musicians and the actors involved in producing their music. Indeed, musicians recognize the impact that such media attention can have in helping them sustain nascent musical careers (Brennan 222) and record company publicists often measure success in column inches of press coverage (Negus 124). Moreover, beyond the impact that media discourse can have on individual actors within the field of popular music, it can also provide a legitimating ideology that elevates the status of the entire field (Baumann).

Yet, despite its widely recognized significance, Steve Jones (1) notes that popular Music discourse has been the subject of little systematic study and scholarly publication. Although recent years have seen more attention to the popular music press (Atton; Jones; Lindberg et al.), much of this research focuses on American and British rock criticism in specialty magazines or fanzines (for exceptions, see Pires; Schmutz "Social and Symbolic"; van Venrooij and Schmutz). While such studies have 
provided key insights into the evolution of a burgeoning popular music discours particularly since the emergence of rock criticism in the 1960s, less is written about the position of popular music journalism in "quality" papers, and few systematic comparisons have been made across countries. Thus, we aim to contribute to the growing body of scholarship by documenting general features of popular music coverage in elite newspapers from the US, France, Germany, and the Netherlands between 1955 and 2005.

There are a number of reasons why the coverage of popular music in elite newspapers is a useful focus of inquiry. While popular music discourse in specialty magazines, fanzines, and like media can certainly be influential (see Schmutz "Retrospective"), coverage in elite newspapers is a better indicator of society-wide legitimacy. In other words, we might consider discourse about popular music in specialty publications to be a source of "local validation," while coverage of popular music in national or supra-regional newspapers represents a more "general validation" of the cultural form, and indicates that it has received more widespread acceptance in society (Johnson, Dowd and Ridgeway). Coverage in such "prestige" media outlets is a source of cultural legitimacy, because "they are produced by and for societal elites, aspirants to elite status, and other participants in the cultural mainstream" (Deephouse and Suchman 56). Thus, popular music discourse in these newspapers provides a glimpse of the distinction between "legitimate" and illegitimate culture (Bourdieu) in the four countries at different time periods. On a pragmatic note, as Peterson suggests, newspaper coverage represents a plentiful and accessible data source for making longitudinal, cross-national comparisons.

Drawing on a larger study of journalistic attention to arts and culture in the four countries, we focus on broad changes and continuities in the extent, form, and focus of popular music coverage in mainstream media outlets. First, we demonstrate the rising prominence of popular music in the quality papers as indicated by the amount of editorial space it receives relative to classical music. Second, we address the focus of popular music coverage by noting the genres that rise and fall in prominence within each country. Finally, we trace shifts in the role of the popular music journalist by considering the prevalence of concert and album reviews, interviews, and other forms of media coverage. Our longitudinal and cross-national approach allows us to highlight changes and continuities within each country, as well as to identify areas of transnational convergence and national distinctiveness in popular music since 1955.

\section{Media Discourse and Cultural Legitimacy}

In a variety of cultural fields, ranging from American film to French cuisine, scholars have demonstrated the role of critical discourse in elevating the status of particular cultural genres. For instance, Baumann shows how film critics writing for mainstream American newspapers and magazines provided a legitimating ideology that enabled Hollywood film to be seen as art. After 1960, such critics increasingly incorporated "high art" reviewing techniques and a more intellectualizing discourse, which 
enhanced the position of film in the cultural hierarchy. Similarly, in 19th-century France, the development of an expansive culinary discourse transformed the "material into the intellectual, the imaginative, the symbolic, and the aesthetic" and thereby raised the cultural standing of French cuisine (Ferguson 610).

Parallel arguments have been put forward in the case of popular music. In the case of jazz, enthusiasts and critics produced a discourse that helped elevate the genre beyond its initial "lowbrow" status (Jackson; Lopes). Jazz criticism eventually moved out of the fanzines and specialty publications, and into more mainstream magazines, both indicating and enhancing its cultural standing. In the same way, Regev has argued that, beginning in the 1960s, critics sought to reshape rock music as a legitimate art. Comparable to the way in which auteur theory was adopted by film critics, he suggests that rock critics emphasized the authorial autonomy of rock musicians and created a canon of rock "artists," thereby legitimating rock as an art form ("Producing"). Furthermore, the rock aesthetic diffused to discourses about other forms of popular music, which contributed to the general cultural legitimacy of popular music (Regev "Rock Aesthetics"). In seeking to articulate the difference between rock music and entertainment, other scholars agree that critics have successfully made it clear that "popular music may attain the status of at least semilegitimate culture” (Gudmundsson et al. 59). At the same time, however, we do not expect that popular music has experienced the same degree of aesthetic mobility in the four countries.

The US, France, Germany, and the Netherlands were selected because they vary along key dimensions theoretically relevant to cultural classifications and hierarchies. In the international cultural arena, the US holds a prominent-some argue hegemonic - position, while the Netherlands holds a less conspicuous place, and has a much smaller cultural economy; France and Germany occupy middle positions in this regard. Such variation between the four countries in terms of size and centrality to cultural production systems bears theoretical relevance. As Janssen demonstrates in her study of fashion reporting from 1955-2005, French newspapers have traditionally paid more attention to designer fashion, particularly to French designers, correspondent with their centrality in global fashion production ("Fashion Reporting”). Yet, as France's influence in designer fashion has diminished, their fashion reporting has recently become more international in its scope, while Dutch and German newspapers have lately expanded their fashion reporting as their own domestic designer fashion industries have emerged and grown.

Cultural policy and education may also affect openness to certain music genres, and the degree to which popular music is integrated into school curricula. For instance, whereas cultural policies in France have limited cultural imports, the Netherlands has typically been open to foreign, including American, cultural products. In addition, cultural education in France, Germany, and the Netherlands varies considerably in its orientation to international cultural products, and the degree to which it focuses on classical or "high" cultural forms. In his analysis of secondary-school examinations for music and art, Bevers finds that the Netherlands places the least emphasis on 
canonical works and is most likely to include the culture of other nations, and popular culture-including popular music - in its curricula, while France and Germany show the greatest propensity to focus on domestic culture, as well as on the classical canon and high cultural forms. This is also evident in newspaper reviews of popular music albums, in which German critics rely much more on "high art" discourse and reviewing techniques than do their Dutch or American counterparts (van Venrooij and Schmutz).

Thus, part of our aim is to understand the position of popular music within the cultural hierarchies of the four countries. As such, we focus on the extent to which popular music is covered by elite newspapers in each country, as well as how that space is distributed among a wide variety of popular music genres. In addition, we consider the role of the popular music journalist and critic, by looking at the types of articles they write about popular music, in each country and across time.

\section{Research Method}

Before turning to the findings, we will briefly discuss the research methodology employed in our study. Media attention to music was measured through detailed content analysis of newspapers in the US, France, Germany, and the Netherlands in four sample years: 1955, 1975, 1995, and 2005. The newspapers selected are widely circulated at a national or supra-regional level, and were in print from 1955 to 2005. In the European countries, the two newspapers with the average largest paid circulation during the study period were sampled: Le Monde and Le Figaro in France; Frankfurter Allgemeine Zeitung and Suddeutsche Zeitung in Germany; NRC Handelsblad and de Volkskrant in the Netherlands. For the US, the New York Times and the Los Angeles Times are the papers included. All the papers selected target an elite readership and shape how the public and other media outlets discuss popular music. To control for seasonal variation, the sample is stratified by quarter, with one edition selected at random for each day of the week in each quarter, producing four constructed weeks per sample year (twenty-four or twenty-eight editions in each country per year).

The fourteen coders on the project coded all articles related to arts and culture, but this paper is based on the 4,038 articles in the sample about music, particularly the 1,867 articles related to popular music. The music articles were coded as being either about "classical" or "popular" music and were additionally classified into a variety of subgenres. In doing so, we use a broad definition of popular music as consisting of jazz, rock, R\&B, blues, country, electronica, “pop” music (i.e. Top 40), world music, easy listening, brass band, and various regional genres such as chanson (France), schlager (Germany), and smartlap and kleinkunst (the Netherlands). In this paper, some of the above genres are a combination of one or more subgenres. Jazz includes eight subgenres, ranging from big band to bebop to bossa nova; rock includes punk and heavy metal; country includes bluegrass; electronica includes disco, techno, and house; and world music is comprised of subgenres from multiple regions. 
In addition to the coding, each article was measured in square centimeters, to provide a key indicator of the amount of space given to popular music by each newspaper. To give an idea of the relative position of popular music, rather than of its absolute amount of space only, we provide comparisons with the amount of newspaper space occupied by classical music. Finally, the type of article was coded as being a review, interview, news item, preview, announcement, background, opinion, or regular column. In the case of reviews, we also distinguish between reviews of albums and live performances to highlight the role of the popular music critic. The sections that follow report the findings of our study.

\section{The Rising Prominence of Popular Music}

Table 1 shows the number of articles as well as the average size and total space devoted to popular and classical music. In general, the findings point to the increasing legitimacy of popular music over time in all four countries. However, the size and timing of that shift varies substantially across countries. In particular, the US exhibits a much larger increase in popular music coverage relative to classical music coverage between 1955 and 1975 , moving from $11.9 \%$ to $47.1 \%$ of the total space while none of the European countries allot more than $21.8 \%$ of the space to popular music in 1975. By 1995, however, the US, France, and the Netherlands all devote more newspaper space to popular music than to classical music. Meanwhile, Germany stands out in the relatively low amount of attention it gives to popular music, with classical music occupying more than twice as much space in the elite newspapers. Although the German newspapers pay a little more attention to popular music in 2005, it is still less than $40 \%$ of the overall space devoted to music; France still gives a majority of space to popular music (53.8\%), and the US and the Netherlands give nearly two-thirds of the space to popular music (64.1\% and $66.3 \%$, respectively).

Thus, it would appear that the rock criticism which emerged in the late 1960s and early 1970s in the four countries was not as readily embraced by French, German, or Dutch newspapers. During this period in the US, magazines like Crawdaddy (1966), Rolling Stone (1967), and Creem (1969) introduced a more serious treatment of rock and popular music that evidently found acceptance in elite newspapers by 1975. A stable venue for popular music coverage emerged in France around the same time with the founding of Rock \& Roll (1966) and Best (1968), but this does not appear to have led to widespread acceptance in the quality papers. In fact, French newspapers actually paid less attention to popular music in 1975 relative to 1955 , despite the fact that a popular music press did not came into being in France until the late 1960s (Pires). Likewise, the Dutch popular music magazine Oor (originally called Muziekkrant Oor) was founded in 1971 and quickly found a loyal readership, but this seems to have made little impact on the legitimacy of popular music as reflected in the elite papers of the Netherlands during its early years.

As noted, Germany is notable for the continuing lack of attention to popular music in its mainstream newspapers. Although, as in other countries, rock criticism emerged 
Table 1 Increasing newspaper attention to popular music

\begin{tabular}{|c|c|c|c|c|c|c|c|c|c|}
\hline & & \multicolumn{2}{|c|}{ USA } & \multicolumn{2}{|c|}{ France } & \multicolumn{2}{|c|}{ Germany } & \multicolumn{2}{|c|}{ Netherlands } \\
\hline & & $\begin{array}{c}\text { Classical } \\
\text { music }\end{array}$ & $\begin{array}{c}\text { Popular } \\
\text { music }\end{array}$ & $\begin{array}{c}\text { Classical } \\
\text { music }\end{array}$ & $\begin{array}{c}\text { Popular } \\
\text { music }\end{array}$ & $\begin{array}{c}\text { Classical } \\
\text { music }\end{array}$ & $\begin{array}{c}\text { Popular } \\
\text { music }\end{array}$ & $\begin{array}{c}\text { Classical } \\
\text { music }\end{array}$ & $\begin{array}{c}\text { Popular } \\
\text { music }\end{array}$ \\
\hline \multirow[t]{3}{*}{1955} & \# of articles & 403 & 83 & 54 & 28 & 72 & 8 & 117 & 13 \\
\hline & Mean $\mathrm{cm}^{2}$ & 73.7 & 48.5 & 82.6 & 91.7 & 122.0 & 99.6 & 95.8 & 178.1 \\
\hline & Total space & $88.1 \%$ & $11.9 \%$ & $63.5 \%$ & $36.5 \%$ & $91.7 \%$ & $8.3 \%$ & $82.9 \%$ & $17.1 \%$ \\
\hline \multirow[t]{3}{*}{1975} & \# of articles & 215 & 153 & 90 & 26 & 96 & 20 & 136 & 52 \\
\hline & Mean $\mathrm{cm}^{2}$ & 112.6 & 140.9 & 113.2 & 109.3 & 210.8 & 168.9 & 202.1 & 134.0 \\
\hline & Total space & $52.9 \%$ & $47.1 \%$ & $78.2 \%$ & $21.8 \%$ & $85.7 \%$ & $14.3 \%$ & $79.8 \%$ & $20.2 \%$ \\
\hline \multirow[t]{3}{*}{1995} & \# of articles & 155 & 308 & 120 & 206 & 122 & 79 & 103 & 152 \\
\hline & Mean $\mathrm{cm}^{2}$ & 260.7 & 221.6 & 125.0 & 125.6 & 263.0 & 186.7 & 228.7 & 275.8 \\
\hline & Total space & $37.2 \%$ & $62.8 \%$ & $36.7 \%$ & $63.3 \%$ & $68.5 \%$ & $31.5 \%$ & $36.0 \%$ & $64.0 \%$ \\
\hline \multirow[t]{3}{*}{2005} & \# of articles & 127 & 284 & 91 & 123 & 142 & 99 & 128 & 233 \\
\hline & Mean $\mathrm{cm}^{2}$ & 363.4 & 290.2 & 198.2 & 170.6 & 315.4 & 288.3 & 218.7 & 236.6 \\
\hline & Total space & $35.9 \%$ & $64.1 \%$ & $46.2 \%$ & $53.8 \%$ & $61.1 \%$ & $38.9 \%$ & $33.7 \%$ & $66.3 \%$ \\
\hline
\end{tabular}


in the late 1960s (including Music Express in 1969), popular music was still largely excluded from the national newspapers in 1975, much as in France and the Netherlands. Yet, unlike in its European counterparts, popular music continues to be overshadowed by classical music in 1995 and 2005. One factor that may help to explain the early acceptance of popular music in the American papers and the continued focus on classical music in German papers relates to the centrality of each country in the production of such music. As Janssen et al. show, the centrality of a country in the production of a given cultural product shapes the extent to which media attention focuses on domestic, rather than international, actors in that field. In the US, which occupies a central position in the production of popular music, it is understandable that American newspapers embraced popular music more readily, while German centrality in the classical music field (see Applegate and Potter) might account for the continued attention to such music in the elite papers.

Beyond differences in the amount of attention to popular music, van Venrooij and Schmutz find that German newspapers also differ in how they review popular music albums. In their study of recent American, German, and Dutch popular music reviews in elite newspapers, they find that, although German reviews are less frequent, they are much longer and critics use more "intellectualizing" discourse and "high art" criteria than do reviewers in the US or the Netherlands. Taken together with the present findings, it appears that the intellectualizing style of German popular music critics may be partly an attempt to legitimate popular music by drawing on the type of discourse applied to classical music, which is clearly placed above popular music in the German cultural hierarchy. This interpretation is also consistent with Bevers's findings regarding secondary-school examinations in art and music, which showed that the educational system does not legitimate popular music in Germany, whereas Dutch examinations do include knowledge of popular music. In the case of France, it appears that the elite newspapers are perhaps slightly more open to popular music than is the country's educational system, which focuses more exclusively on French culture and classical music. Thus, there is considerable variation in the cultural hierarchies of the four countries, even though the overarching trend has been towards more "general validation" of popular music as indicated by its inclusion in the pages of elite newspapers.

\section{Patterned Inclusion of Popular Music}

We wish now to turn to the question of which genres benefit from the growing attention given to popular music. While the general trend of increasing coverage in elite newspapers indicates a greater cultural legitimacy for popular music, a closer look at the distribution of this attention suggests that there are patterned limits to the inclusion of popular music. In other words, certain genres benefit more than others from this process of legitimation, and this varies across countries. Table 2 lists the five genres that had the highest number of articles in each reference year for the four countries. 
Table 2 Distribution of popular music articles by genre

\begin{tabular}{|c|c|c|c|c|c|c|c|c|}
\hline \multirow{3}{*}{1955} & \multicolumn{2}{|c|}{ USA } & \multicolumn{2}{|c|}{ France } & \multicolumn{2}{|c|}{ Germany } & \multicolumn{2}{|c|}{ Netherlands } \\
\hline & \multicolumn{2}{|c|}{ Top genres by \# of articles } & \multicolumn{2}{|c|}{ Top genres by \# of articles } & \multicolumn{2}{|c|}{ Top genres by \# of articles } & \multicolumn{2}{|c|}{ Top genres by \# of articles } \\
\hline & Jazz & $43.8 \%$ & Chanson & $53.8 \%$ & Jazz & $50.0 \%$ & Chanson & $40.0 \%$ \\
\hline & Easy & & Jazz & $30.8 \%$ & Schlager & $16.7 \%$ & Brass band & $40.0 \%$ \\
\hline & listening & $30.0 \%$ & Other & $15.4 \%$ & Chanson & $16.7 \%$ & Jazz & $10.0 \%$ \\
\hline & World & $7.5 \%$ & & & Other & $16.7 \%$ & Easy & \\
\hline & Film & $6.3 \%$ & & & & & listening & $10.0 \%$ \\
\hline & Country & $5.0 \%$ & & & & & & \\
\hline \multirow[t]{6}{*}{1975} & Jazz & $26.8 \%$ & Chanson & $40.9 \%$ & World & $26.3 \%$ & Jazz & $47.5 \%$ \\
\hline & Rock & $24.8 \%$ & World & $18.2 \%$ & Rock & $21.1 \%$ & Rock & $15.0 \%$ \\
\hline & Electronica & $9.2 \%$ & Jazz & $13.6 \%$ & Chanson & $21.1 \%$ & Dutch & \\
\hline & Easy & & $\mathrm{R} \& \mathrm{~B}$ & $9.1 \%$ & Schlager & $10.5 \%$ & music* & $10.0 \%$ \\
\hline & listening & $7.8 \%$ & Country & $4.5 \%$ & Jazz & $5.3 \%$ & World & $5.0 \%$ \\
\hline & World & $7.8 \%$ & & & & & Other pop & $5.0 \%$ \\
\hline \multirow[t]{5}{*}{1995} & Rock & $30.2 \%$ & Jazz & $31.7 \%$ & Jazz & $23.1 \%$ & Rock & $27.0 \%$ \\
\hline & Jazz & $17.0 \%$ & Rock & $21.3 \%$ & Rock & $21.5 \%$ & Jazz & $21.3 \%$ \\
\hline & Electronica & $9.4 \%$ & World & $13.4 \%$ & World & $10.8 \%$ & Electronica & $13.5 \%$ \\
\hline & Country & $6.3 \%$ & Chanson & $9.8 \%$ & Electronica & $7.7 \%$ & World & $11.3 \%$ \\
\hline & World & $6.3 \%$ & Electronica & $9.1 \%$ & Schlager & $4.6 \%$ & Other pop & $7.1 \%$ \\
\hline \multirow[t]{5}{*}{2005} & Rock & $27.2 \%$ & Jazz & $23.4 \%$ & Rock & $43.9 \%$ & Rock & $29.3 \%$ \\
\hline & Jazz & $14.7 \%$ & World & $18.0 \%$ & Electronica & $19.5 \%$ & Electronica & $14.9 \%$ \\
\hline & Electronica & $13.6 \%$ & Rock & $17.1 \%$ & Jazz & $9.8 \%$ & Jazz & $14.9 \%$ \\
\hline & Rap & $8.8 \%$ & Chanson & $11.7 \%$ & World & $3.7 \%$ & World & $10.1 \%$ \\
\hline & Country & $8.8 \%$ & Electronica & $10.8 \%$ & Rap & $3.7 \%$ & Rap & $5.8 \%$ \\
\hline
\end{tabular}

Note: Dutch music $=$ smartlap, kleinkunst. 
The distribution of space by genre in elite American newspapers appears to mirror patterns of elite music preferences. One explanation for the erosion of traditional hierarchies that once made strong distinctions between "high" culture and popular fare is the growing eclecticism of elite tastes in recent decades. As Peterson and Kern suggest, elites in the US have gone from being "univores" that consume exclusively classical music to being "omnivores” that are familiar with, and enjoy, a wide range of music genres. At the same time, however, Bryson finds that, although high-status individuals in the US do have greater knowledge and appreciation of a wide range of genres, they often exclude musical forms associated with low-status groups, such as heavy metal and country. In both ways, the newspaper coverage of popular music in the US appears compatible with research on elite music preferences. Even as elite newspapers become more eclectic and cover a wider range of genres, certain genres are notably absent, or limited, in their coverage. In particular, although a wide range of rock music genres, including punk, receive media coverage, heavy metal receives very little attention. In 1995, for example, eighty-seven articles are categorized as rock music in US newspapers, only three of which focus on heavy metal music. And, although country music does receive a boost in attention following the introduction in 1992 of SoundScan, which revealed it to be more popular than assumed (Anand and Peterson), it receives much less attention than rock or jazz. Again, although rap receives more attention in 2005 relative to 1995, it remains somewhat peripheral. At the same time, coverage of rap music is much greater in the US than in other countries, despite its global diffusion (Basu and Lemelle), which may be due to American centrality in this musical form. In general, though, it appears to be rock music that benefits most from the greater attention to popular music in the American newspapers.

It is not only the newspapers in the US that devote burgeoning space for popular music primarily to rock. Although their overall increases in popular music coverage are modest in 1975, both Germany and the Netherlands see rock music emerge as the second most covered popular genre. In 1995 and 2005, the Dutch papers devote more articles to rock music than any other popular genre, while in Germany rock takes up nearly half of all popular music articles in 2005 (43.9\%). France, on the other hand, is marked by its lack of attention to rock music in 1975, which does not even register among the top five genres. Given that chanson receives the most newspaper articles by far in 1975, a plausible explanation would seem to be that French papers rejected foreign popular music in favor of domestic popular music. While the other genres covered (including world and jazz) suggest some openness to non-French musical styles, jazz is one that had already been legitimated and "made French" several decades earlier (Jackson). Furthermore, publications like Rock \& Folk and Best had attracted a substantial readership by concentrating on rock music, the former primarily on Anglophone rock musicians and the latter on French rock performers. Thus, it would seem that popular musical forms, with the exception of chanson, did not ascend the cultural hierarchy in France until later years, and rock music continues to have a less central position in elite French newspapers than it does in the other countries. 
In general, France and the Netherlands appear similar to the US in terms of the increasing eclecticism of music coverage in their newspapers. Such trends are consistent with the eclecticism of elite cultural preferences in both countries (see Coulangeon, Ravet, and Roharik in France; Van Eijck and Van Rees in the Netherlands). Both countries feature several popular genres that attract a good number of newspaper articles, while Germany seems to move towards a more exclusive focus on rock music and, secondarily, on electronica. However, the enhanced position of rock music in elite German newspapers does not extend to all of its forms. In 2005, the sample contains thirty-six articles on rock music, but none deal with heavy metal. Another notable exclusion is the lack of coverage of rap music, particularly in France and Germany, despite its international popularity. In both countries, rap has become a popular and visible form of musical expression, particularly in immigrant communities (for France, see Helenon; for Germany, see Bennett; Brown), but it is the subject of little attention in French and German newspapers.

In contrast, the elite newspapers in the Netherlands give relatively more space to rap, but are notable for the lack of attention that they give to Dutch popular genres. Whereas in France, chanson continues to rank among the top five genres in all sample years, and German schlager remains so in 1995. Dutch smartlap and Berkers kleinkunst are largely overlooked in 1995 and 2005. This may be partly because of the relatively peripheral position of the Netherlands in the production of popular music, and also due to its general openness to foreign, particularly American and British, cultural products (Janssen, Kuipers, and Verboord).

Thus, the increasing prominence of popular music privileges some genres over others, even though all four countries cover a wider range of music over time. Certain genres (heavy metal in the US and Germany, rap in France and Germany, smartlap and kleinkunst in the Netherlands) remain outside the purview of the elite newspapers and their legitimating power.

\section{The form of Popluar Music Coverage}

It is generally acknowledged that, prior to the 1960s, much press attention to popular music was limited to news and gossip about pop stars (Lindberg et al.; Pires). The emergence of new outlets for rock criticism represented a shift in focus toward a more evaluative and critical approach to popular music. To what degree did the elite newspapers adopt the more evaluative style of critics in the specialty magazines and underground press? Examining the types of articles published about popular music allows us to record the ways in which this impacted on the approach to popular music in elite newspapers, and the roles that their journalists assumed in their coverage of popular music. Table 3 summarizes the commonest types of article about popular music that appeared in the elite newspapers.

News items (stories in which a topical event is signaled and described) were the commonest form of popular music coverage in the US, France, and the Netherlands in 1955. In Germany, announcements — short information pieces of ten to thirty lines, 
Table 3 Distribution of popular music articles by article type

\begin{tabular}{|c|c|c|c|c|c|c|c|c|}
\hline \multirow{3}{*}{1955} & \multicolumn{2}{|c|}{ USA } & \multicolumn{2}{|c|}{ France } & \multicolumn{2}{|c|}{ Germany } & \multicolumn{2}{|c|}{ Netherlands } \\
\hline & \multicolumn{2}{|c|}{ Article types } & \multicolumn{2}{|c|}{ Article types } & \multicolumn{2}{|c|}{ Article types } & \multicolumn{2}{|c|}{ Article types } \\
\hline & News & $48.2 \%$ & News & $50.0 \%$ & Announce & $37.5 \%$ & News & $30.8 \%$ \\
\hline & Reviews & $36.1 \%$ & Reviews & $32.1 \%$ & Background & $25.0 \%$ & Reviews & $30.8 \%$ \\
\hline & Announce & $6.0 \%$ & Announce & $10.7 \%$ & News & $12.5 \%$ & Background & $23.1 \%$ \\
\hline & Background & $4.8 \%$ & Interview & $3.6 \%$ & Reviews & $12.5 \%$ & Announce & $15.4 \%$ \\
\hline & Interview & $2.4 \%$ & Preview & $3.6 \%$ & Opinion & $12.5 \%$ & & \\
\hline 1975 & Reviews & $54.7 \%$ & Announce & $50.0 \%$ & News & $40.0 \%$ & Reviews & $44.2 \%$ \\
\hline & Announce & $18.7 \%$ & Reviews & $26.9 \%$ & Reviews & $30.0 \%$ & News & $26.9 \%$ \\
\hline & Background & $13.3 \%$ & News & $7.7 \%$ & Background & $15.0 \%$ & Announce & $13.5 \%$ \\
\hline & News & $7.3 \%$ & Interview & $7.7 \%$ & Announce & $10.0 \%$ & Interview & $5.8 \%$ \\
\hline & Interview & $3.3 \%$ & Background & $7.7 \%$ & Opinion & $5.0 \%$ & Column & $3.8 \%$ \\
\hline 1995 & Reviews & $30.8 \%$ & Announce & $49.0 \%$ & Reviews & $35.4 \%$ & Reviews & $49.7 \%$ \\
\hline & News & $23.9 \%$ & Reviews & $16.5 \%$ & News & $26.6 \%$ & News & $23.2 \%$ \\
\hline & Background & $19.3 \%$ & News & $15.5 \%$ & Background & $24.1 \%$ & Background & $10.6 \%$ \\
\hline & Announce & $16.1 \%$ & Background & $10.2 \%$ & Announce & $7.6 \%$ & Interview & $9.9 \%$ \\
\hline & Opinion & $6.6 \%$ & Interview & $6.8 \%$ & Preview & $3.8 \%$ & Opinion & $3.3 \%$ \\
\hline 2005 & Reviews & $29.9 \%$ & Reviews & $33.3 \%$ & News & $32.3 \%$ & Reviews & $42.2 \%$ \\
\hline & News & $27.1 \%$ & Announce & $31.7 \%$ & Reviews & $30.3 \%$ & News & $24.1 \%$ \\
\hline & Background & $22.2 \%$ & News & $15.4 \%$ & Background & $19.2 \%$ & Background & $10.8 \%$ \\
\hline & Announce & $12.7 \%$ & Background & $13.0 \%$ & Announce & $14.1 \%$ & Announce & $9.9 \%$ \\
\hline & Interview & $4.2 \%$ & Interview & $4.1 \%$ & Interview & $4.0 \%$ & Interview & $9.1 \%$ \\
\hline
\end{tabular}


publicizing the availability of a new product-were the commonest form of popular music article at the time. However, a substantial number of popular music reviews were published in 1955, albeit to a lesser extent in Germany; these include reports on products - typically albums or live performances - that contain evaluative elements, in addition to descriptive ones. Yet due to the limited amount of space given to popular music in 1955, the actual number of reviews is small, despite the fact that they comprise over $30 \%$ of popular music articles in the US, France, and the Netherlands. In the US, the thirty reviews in the sample focus almost exclusively on reviews of jazz albums, a popular genre that had already achieved considerable legitimacy, in part due to the earlier emergence of jazz criticism in specialty publications (see Lopes). The nine popular music reviews published in France in 1955 concentrated primarily on live performances of chanson and, to a lesser extent, jazz, while the four reviews in Dutch newspapers also considered live chanson performances in the Netherlands.

By 1975, reviews had become much more common in American and Dutch newspapers, occupying a majority of popular music coverage in the US (54.7\%) and more than $40 \%$ in the Netherlands. As noted previously, however, the total amount of space devoted to popular music was much higher in the US relative to other countries in that year. While some jazz reviews continued to appear in the American papers, the coverage was dominated by reviews of rock music, both albums and live performances. In general, this provides additional support to the idea that the rock criticism of the 1960s found readier acceptance in American elite newspapers than in other countries. All popular music reviews in the Dutch papers during 1975 focused on jazz and rock music; thus, although the emergence of rock criticism did not lead to a large overall increase in popular music attention in the Netherlands, it does appear that Dutch journalists adopted the more critical approach to popular music characteristic of publications like Muziekkrant Oor. By contrast, the 1975 sample of French and German papers contains only seven and six reviews, respectively, and does not cluster around any particular genre, which further suggests that elite newspapers in these two countries did not readily embrace the critical approach that had emerged in popular music-especially rock music_-magazines.

By 1995, reviews are the commonest type of popular music article in each country, except France. The general increase in attention to popular music in all four countries seems to contribute to a greater variety in the types of articles published. In the US, for example, reviews are the commonest kind of article, but news, background articles, and announcements all appear in good numbers, along with some opinion pieces. Reviews, news, and background articles are common in Germany, while France maintains a large number of announcements. In the US, reviews are mostly of rock music, but a significant number concentrate on jazz, and some on country or world music. Reviews in Germany are largely of live rock performances in 1995, and a few of jazz and world music. By contrast, Dutch reviews in this year are most often of rock albums, but also of albums (or performances) of jazz, world, country, blues, and other genres. French newspapers focus primarily on reviews of rock and jazz albums in 1995. Overall, it appears that the more critical approach of music reviews is widely 
accepted by 1995, and that this style is directed at genres beyond rock and jazz, which may lend support to Regevs claim that the evaluative criteria espoused by early rock critics diffused throughout the field and became the standard by which other popular musical forms are assessed ("Rock Aesthetics").

By 2005, the review appears to be well established in all four countries, accounting for about 30\% or more of all popular music articles in the US, France, and Germany, and more than $40 \%$ of articles in the Netherlands. In both the American and Dutch papers, rock and jazz continue to receive most reviews, but a growing number of reviews appear for a wider variety of music genres. French reviewers divide their critical attention fairly equally between rock, jazz, and world music, while German reviews are focused almost entirely on rock albums. Thus, although it has become a widely accepted format, there is considerable variation in the focus of popular music reviews over time, and across countries, To the extent that critical attention to certain genres signals the broader cultural legitimacy of those genres, it appears that a wider range of popular musics are legitimated in the US and the Netherlands. By comparison, rock, jazz, and world music appear to be the most legitimated popular genres in France, and rock music stands out as the primary beneficiary of the legitimating attention of elite newspapers in Germany. In general, the role of the popular music journalist appears to have increasingly become that of "critic" as they more often produce evaluative information alongside news, announcements, and other descriptive accounts.

\section{Conclusion}

Popular music has attracted significantly more attention in the elite newspapers of the US, France, Germany, and the Netherlands since 1955. The larger number of popular music genres covered and greater variety in the types of articles written about them suggest that popular music has gained cultural legitimacy in the four countries. At the same time, however, the findings show that there is considerable variation across countries, with Germany remaining the least open to popular music, while the US and the Netherlands have become the most inclusive of popular music. Furthermore, the findings generally support the idea that the emergence of rock criticism in the 1960s had a profound effect on subsequent media discourse about popular music. Although its impact took longer to become apparent in the European countries in our study, the amount of space given to popular music, as well as the shift toward a more critical and evaluative approach, suggests that the style of writing about rock music became more generally adopted by elite newspapers. It is also important to note that the benefits of greater legitimacy and newspaper space are not distributed evenly, as less legitimate genres are often overlooked. Other research shows that female musicians were most excluded from newspaper coverage of the genres that gained the most legitimacy in each country (Schmutz "Social”). Thus, there are patterned limits to the inclusion of popular music and musicians in elite newspapers. Finally, the present study highlights certain areas of transnational convergences and distinctiveness in the increasingly 
"global” cultural field of popular music. In particular, it suggests that size, centrality of cultural production, educational systems, cultural policy, and elite taste are among the factors that contribute to a complex relationship between popular music and society.

\section{Acknowledgment}

This research was supported by the Netherlands Organization for Scientific Research as part of the VICI project Cultural Classification Systems in Transition (NOW-project 277-45-001). The authors gratefully acknowledge Tim Dowd who provided thoughtful comments on an earlier draft of this paper.

\section{References}

Anand, Narasimhan and Richard A. Peterson. "When Market Information Constitutes Fields.” Organization Science, 11 (2000): 270-284.

Applegate, Celia and Pamela Potter. Music and German National Identity. Chicago, IL: University of Chicago Press, 2002.

Atton, Chris. "Writing About Listening: Alternative Discourses in Rock Journalism." Popular Music 28 (2009): 53-67.

Basu, Dipannita and Sidney J. Lemelle, Eds. The Vinyl Ain't Final. Ann Arbor, MI: Pluto Press, 2006.

Baumann, Shyon. "Intellectualization and Art World Development: Film in the United States.” American Sociological Review 66 (2001): 404-426.

Becker, Howard S. Art Worlds. Berkeley: University of California Press, 1982.

Bennett, Andy. “Hip-Hop am Main, Rappin’ on the Tyne: Hip-Hop Culture as a Local Construct in Two European Cities.” That's the Joint! The Hip-Hop Studies Reader, Eds. Murray Forman and Mark Anthony Neal. London: Routledge, 2004. 177-200.

Bevers, Ton. "Cultural Education and the Canon: A Comparative Content Analysis of Secondary School Exams for Music and Art in England, France, Germany and the Netherlands, 1990-2004.” Poetics 33 (2005): 388-416.

Bourdieu, Pierre. The Field of Cultural Production. New York: Columbia University Press, 1993.

Brennan, Matt. "The Rough Guide to Critics: Musicians Discuss the Role of the Music Press.” Popular Music 25 (2006): 221-234.

Brown, Timothy S. "'Keeping it Real in a Different 'Hood: (African-)Americanization and Hip Hop in Germany.” The Vinyl Ain’t Final. Eds. Dipannita Basu and Sidney J. Lemelle. Ann Arbor, MI: Pluto Press, 2006. 137-150.

Bryson, Bethany. "'Anything but Heavy Metal': Symbolic Exclusion and Musical Dislikes.” American Sociological Review, 61 (1996): 884-899.

Deephouse, David L. and Mark Suchman. "Legitimacy in Organizational Institutionalism.” The Sage Handbook of Organizational Institutionalism. Eds. Royston Greenwood, Christine Oliver, Roy Suddaby, and Kerstin SahlinAndersson. London: Sage, 2008. 49-77. 
Ferguson, Priscilla Parkhurst. “A Cultural Field in the Making: Gastronomy in $19^{\text {th }}$ Century France.” American Journal of Sociology 104 (1998): 597-641.

Gudmundsson, Gestur, Ulf Lindberg, Morten Michelsen, and Hans Weisenthaut. "Brit Crit: Turning Points in British Rock Criticism, 1960-1990.” Ed. Steve Jones. Pop Music and the Press. Philadelphia: Temple University Press, 2002. 41-64.

Helenon, Veronique. “Africa on their Mind: Rap, Blackness, and Citizenship in France.” The Vinyl Ain’t Final. Eds. Dipannita Basu and Sidney J. Lemelle. Ann Arbor, MI: Pluto Press, 2006. 151-166.

Jackson, Jeffrey H. Making Jazz French. Durham, NC: Duke University Press, 2003.

Janssen, Susanne. “Fashion Reporting in Cross-national Perspective 1955-2005.” Poetics 34 (2006): 383-406.

Janssen, Susanne, Kuipers, Giselinde, and Marc Verboord. “Cultural Globalization and Arts Journalism: The International Orientation of Arts and Culture Coverage in American, Dutch, French and German Newspapers, 1955-2005.” American Sociological Review 73 (2008): 719-740.

Johnson, Cathryn, Timothy J. Dowd, and Cecilia L. Ridgeway. "Legitimacy as a Social Process.” Annual Review of Sociology 32 (2006): 53-78.

Jones, Steve, ed. Pop Music and the Press. Philadelphia: Temple University Press, 2002.

Lindberg, Ulf, Gestur Gudmundsson, Morten Michelsen and Hans Weisenthaut. Rock Criticism From the Beginning. New York: Peter Lang, 2005.

Lopes, Paul. The Rise of a Jazz Art World. Cambridge University Press, 2002.

Negus, Keith. Producing Pop. London: Edward Arnold, 199

Peterson, Richard A. "Problems in Comparative Research: The Example of Omnivorousness.” Poetics, 33 (2005): 259-282.

Peterson, Richard A. and Roger M. Kern. "Changing Highbrow Taste: From Snob to Omnivore.” American Sociological Review, 61 (1996): 900-907.

Pires, Mat. “The Popular Music Press.” Popular Music in France from Chanson to Techno. Eds. Hugh Dauncey and Steve Cannon. Aldershot: Ashgate, 2003. 7796.

Regev, Motti. "Producing Artistic Value: The Case of Rock Music.” Sociological Quarterly 35 (1994): 85-102.

Regev, Motti. "Rock Aesthetics and Musics of the World.” Theory Culture and Society 14 (1997): 125-142.

Schmutz, Vaughn. "Retrospective Cultural Consecration In Popular Music.” American Behavioral Scientist 48(2005): 1510-1523.

Schmutz, Vaughn. "Social and Symbolic Boundaries in Newspaper Coverage of Music, 1955-2005: Gender and Genre in the US France, Germany, and the Netherlands.” Poetics 37 (2009): 298-314.

Shuker, Roy. Understanding Popular Music. London: Routledge, 1994.

Van Eijck, Koen and Kees Van Rees. "Media Orientation and Media Use: Television Viewing Behavior of Specific Reader Types from 1975 to 1995.” Communication Research 27 (2000): 574-616.

Van Venrooij, Alex and Vaughn Schmutz. "The Evaluation of Popular Music in the United States, Germany and the Netherlands: A Comparison of the Use of High Art and Popular Aesthetic Criteria.” Cultural Sociology, forthcoming. 